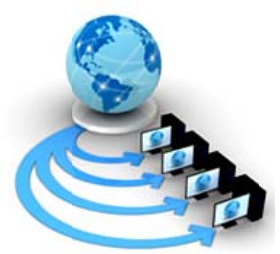

Volume 9, No. 1, January-February 2018

International Journal of Advanced Research in Computer Science

RESEARCH PAPER

\title{
PRIVACY AND SECURITY CONCERN OF CUSTOMERS DOING ONLINE SHOPPING - AN ANALYTICAL STUDY
}

\author{
Ms Ruchi Arora \\ Research Scholar(Computer science) \\ Mewar University, Chittorgarh \\ Rajasthan,India
}

\author{
Dr. Sunil Kumar Muttoo \\ Professor, Department of Computer Science \\ Delhi University \\ New Delhi, India
}

\begin{abstract}
As Internet has provided a channel where online shopping is being done, and creating need for online retailers to understand the perception for customers towards online shopping. The purpose of this research paper is to explore the factors affecting customers in online shopping. First thing done under this study was incorporating relevant literature, and then testing which variables are affecting consumers decisions to purchase goods online. Questionnaire tool was used to gather the data from 300 respondents which was sent through mail as well as distributed personally.
\end{abstract}

Keywords: Online-shopping, Perceptions, E-Commerce, Customers, Customers Perception, Online Retailers

\section{INTRODUCTION TO E-COMMERCE}

Online Shopping (also called as E-Shopping) is included in E-Commerce (Electronic Commerce) that allows customers to buy goods and services directly from the sellers using web browser on the internet[1].E-commerce in India has been experiencing tremendous growth in last one decade, changing the way customers do transactions. Customers today can shop $24 * 7$, be it at their offices, homes or moving. The E-commerce market in India is increasing rapidly in terms of offerings ranging from travel, hotel reservation, books, movies, electronic gadgets, fashion accessories etc. Privacy of the confidential information has become a fear in the minds of the customers with the growth of E-commerce. While it is very difficult to complete a transaction in E-commerce by a customer without providing private information but psychologically users of Ecommerce are unwilling to provide private information if they feel their privacy is not protected [2]. Customers worry about the security and privacy of personal information and fear that it may be misused by people with wrong intentions [3].In the mean time they also worry that their confidential information can also be shared with the intermediary which can cause a risk to their privacy. They are concerned about how their personal information may be treated now or in future after it has been collected. This way confidentiality of information creates a fear in the minds of everyone. So this sheer size and scope of E-Commerce as an industry makes the Data Privacy such an important and critical topic to be studied and researched[3].

\subsection{Problem Statement}

The customer's online shopping behavior and the factors influencing this behavior indicates that $81 \%$ of those who browse web sites for goods and services do not actually make an online purchase (Gupta, 1996; Klein, 1998; Shim, et al., 2001; Westland \& Clark,

1999).The reason for the study shows that consumers' attitude towards online transactions is the main factor that affects online shopping behavior. This attitude, positive or negative, directly influences the decision making and thus is central to a buyer's shopping behavior.

The customers with a positive attitude that conduct online shopping seeks benefits such as convenience, cost saving through cheaper products, choosing among wide variety of products, 24 hours services. So, a customer's decision for making on online shopping is also affected by the varied experiences that they go through while shopping.

According to the study done by various Authors -Bush et al(2000), Atanasov(2001), Mauldin and Arunachalam(2002) , Cassidy and Chae 2006,Staples (2004), Dinev and Hart(2006) , Lanier(2008) , Gupta(2010) , Pierson and Heyman(2011), Wu,Huang,Yen and Popova (2012), Niranjanmurthy(2013), Karve, Sunil(2014),Mathur(2015) have come up with their own study regarding Privacy of confidential information. One of the study done by Atanasov in 2001 revealed that the customers concerns regarding the safety of the financial transactions online can be resolved through the development of sophisticated encryption programme, many customers require additional assurance that their financial data will be held in confidence. Another study revealed that the online retailers should provide clear description of their security procedures and also overcoming resistance to the fear of using credit card online is one of the key tasks that must be undertaken. Another study done by the researcher has mentioned that, some install softwares like 'spyware' on client's machine without the users' knowledge and consent. End-users web-browsing behavious can be observed though these softwares which in turn can be used to provide this confidential data to a specific server[4]. According to one of the researcher," If Internet users gets increasingly concerned about online privacy, the consequences will range from declining to provide personal information to the rejection of the e-commerce or even minimizing the use of Internet"[5]. Another study have brought into notice that several genuine websites also install cookies into the users system to allow the end-users to personalize the web-sites, recognizing the website's registered users, and also remind them of the stored shopping cart information at various online shopping 
sites[6]. This information is obtained for a kind purpose. The confidential information of the users who are doing online shopping could also be acquired through the use of cookies that can be used to keep track of the online browsing habits of the customers[7].. Another study have analyzed that although there is increase in awareness among Indians about online shopping but still people are facing risk in the electronic form of the retail (e-tailing). The major cause of worry due to online shopping is leakage of their personal information, credit card information can be misused, risk of making wrong purchase decision that include unable to compare prices, return certain product, receiving a wrong product, and the purchased product is not performing as per the expectations. Sometimes inconvenience also takes place during online transaction. This is due to the difficulty in submitting orders, delay in receiving the product and there is no proper procedure to cancel the order, sometimes product can also be send to the wrong place[8].

Another study done by (Wolfinbarger \& Gilly, 2001) revealed that customers' online shopping behaviour is also influenced by their personal characteristics. As mentioned by Defeng, Bingchuan, and Li (2006) a customer's attitude towards online shopping is influenced by demography factors, such as gender, age and income. In addition, consumers have different personality, which may influence how they perceive their online shopping behaviour Moreover, there are some barriers which have contributed to the unwillingness of the customers to shop online because they fear their personal information will be stolen or misused by others. Consequently a framework is needed to structure the complex system of effects of these different factors, and develop an in-depth understanding of consumers' attitudes towards Internet shopping and their intentions to shop online.

One of the biggest factors which has emerged out of all above studies that affect the customers' online shopping behaviour is maintaining the security of confidential information which is sent over the internet. According to the survey conducted by Visa, shows that about $91 \%$ of customers are concerned with the security and privacy of data while doing online shopping. Another Study conducted by Boston Consulting group pointed out that $28 \%$ of the customers failed to purchase any product because they did not get the product that they need or they are not able to finish with the transaction [9]."After the customers make a purchase he always concern about the security of the transaction and has the perception that online credit card transactions are unsafe. This is written by Lorna Pappas in Chain Store Age Executive [9].So the major issue is to secure Online Transactions.

So resolution of problems such as credit card protection and privacy protection will definitely assure a good future of ecommerce.

Based on the above study, it is proposed that if organizations focus more on effective privacy policy, security and invest in developing customers trust, they are more likely to retain their customers and improve their business.

Recent work is done on Signcryption scheme to preserve the privacy of the customers' doing online shopping.Signcryption is a public-key cryptographic approach that is the combination of encryption and digital signature which guarantees confidentiality, integrity and non-repudiation[10].

\subsection{Nature of the study}

Our research work is based on testing the behavior of the customers who are doing online shopping.

This is the descriptive study in which the micro nature investigation of the online customers is used. Empirical research will be conducted using primary as well as secondary data. The present research work is analyzed using a statistical tool called SPSS 16 which includes the use of chi- square test, percentile analysis, graphs, correlation analysis etc.

\subsection{Objectives of the study}

- To find out the perception, issues faced and impact of online shopping on different categories of customers by conducting statistical analysis on the data collected.

- To study and analyse the importance of data privacy in the growth of e-commerce as a business.

- To know the behaviour of the customers who are doing online shopping.

- To understand what products are normally purchased by the customers and from where.

- To find out the problems faced by the customers who are doing online shopping.

\section{HYPOTHESIS OF THE STUDY}

For our study, the following set of hypothesis is developed and is tested on Indian Consumers.

\section{Gender of a customer vs Maximum amount spent on online shopping}

Hypothesis 1:

Null Hypothesis: There is no significant relationship between gender and maximum amount customers spend on online shopping.

Alternate Hypothesis: There is a significant relationship between gender and maximum amount customers spend on online shopping.

\section{Age of the customer vs Maximum amount spent on online shopping}

Hypothesis 2:

Null Hypothesis: There is no significant relationship between age and maximum amount spend on online shopping.

Alternate Hypothesis: There is a significant relationship between age and maximum amount spend on online shopping.

\section{Occupation of the customer vs Maximum amount spent on online shopping}

Hypothesis 3:

Null Hypothesis: There is no significant relationship between the occupation and the maximum amount spend on online shopping.

Alternate Hypothesis: There is a significant relationship between the occupation and the maximum amount spend on online shopping. 
4. Consumer's online security and privacy concerns being the barriers vs Not giving the credit card number to unprotected online shopping sites.

Hypothesis 4:

Null Hypothesis: There is no significant relationship between consumer's online security and privacy concerns being the barriers and not giving the credit card number to unprotected online shopping sites.

Alternate Hypothesis: There is a significant relationship between consumer's online security and privacy concerns being the barriers and not giving the credit card number to unprotected online shopping sites.

5. Authenticity or reputation of the online shopping company vs Not giving the credit card number on its website

Hypothesis 5:

Null Hypothesis: There is no significant relationship between the authenticity or reputation of the online shopping company and not giving the credit card number on its website.

Alternate Hypothesis: There is a significant relationship between the authenticity or reputation of the online shopping company and not giving the credit card number on its website.

6. Considering privacy as being important or unimportant vs Using cash on delivery as a preferred method for online shopping

Hypothesis 6:

Null Hypothesis: There is no significant relationship between considering privacy as being important or unimportant and using cash on delivery as a preferred method for online shopping.

Alternate Hypothesis: There is a significant relationship between considering privacy as being important or unimportant and using cash on delivery as a preferred method for online shopping

7. Risk of phishing credit card transactions vs Using credit card as a preferred method for payment on the internet

Hypothesis 7:

Null Hypothesis: There is no significant relationship between risk of phishing credit card transactions and using credit card as a preferred method for payment on the internet.

Alternate Hypothesis: There is a significant relationship between risk of phishing credit card transactions and using credit card as a preferred method for payment on the internet.

8. Risk of phishing credit card transaction vs Using OTP (One Time Password) for secure transactions.

Hypothesis 8:

Null Hypothesis: There is no significant relationship between risk of phishing credit card transaction and using OTP (One Time Password) for secure transactions.

Alternate Hypothesis: There is a significant relationship between risk of phishing credit card transaction and using OTP (One Time Password) for secure transactions.
9. Risk of phishing credit card transaction vs Using antivirus/antispyware software package.

Hypothesis 9:

Null Hypothesis: There is no significant relationship between risk of phishing credit card transaction and using antivirus/antispyware software package.

Alternate Hypothesis: There is a significant relationship between risk of phishing credit card transaction and using antivirus/antispyware software package.

10. Security and privacy being the barriers to online shopping vs Maximum amount people spend on online shopping.

Hypothesis 10:

Null Hypothesis: There is no significant relationship between security and privacy being the barriers to online shopping and maximum amount people spend on online shopping.

Alternate Hypothesis: There is a significant relationship between security and privacy being the barriers to online shopping and maximum amount people spend on online shopping.

\section{Privacy of personal information being considered} important vs Knowledge of $s$ in https://

Hypothesis 11:

Null Hypothesis: There is no significant relationship between privacy of personal information being considered important and knowledge of $\mathrm{s}$ in https://

Alternate Hypothesis: There is a significant relationship between privacy of personal information being considered important and knowledge of $\mathrm{s}$ in https://

\section{PROPOSED STUDY}

The pivotal aim of this study is to evaluate the customer's attitude and perception towards online shopping and what are the factors that shape the customer's perception towards online shopping. If we look at the customers point of view what is the fear in the minds of the customers while doing online shopping. In our study we will collect primary data using Questionnaire method. For this we will prepare a questionnaire in such a way that it will be able to collect all relevant information regarding the customer's attitude towards online shopping. Likert scaling techniques are used to design the questionnaire

\subsubsection{Sampling Method}

This study was conducted by using convenience sampling method. There were 300 respondents in our research study. The respondents who do online shopping were categorized on the basis of their age, gender, occupation, monthly income etc.

\subsubsection{Questionnaire Design}

The design of the questionnaire is based on what data needs to be collected and how to analyse the data. According to the aim and the objective of our research study, the questionnaire is used to collect data, so as to know the attitude and the perceptions of the customer's towards 
online shopping. From this survey the following information will be gathered like products frequently purchased by customers, customer's perception about security and privacy of information, factors that helps to decide which site to use for online shopping, method preferred for payment, factors that helps in buying decision, to know whether people are really concerned about the privacy of confidential information.

The complete questionnaire is given at the end (appendix 1)

\subsection{Data Collection}

The research study understands the different perceptions of the customers doing online shopping. Self-administered questionnaire is used to collect primary data from the online customers. There was a covering letter along with the questionnaire to explain the purpose of the research and we also gave the assurance of confidentiality of information. Before the questionnaire was sent to the respondents the pilot was conducted who helped in making refinement to the layout of the questionnaire and the questions that are there. We have used various research papers, articles to collect the secondary data. for the purpose of review of literature where data from the previous studies was collected for the purpose of reference.

For primary data collection as we have used questionnaire method.Therefore, we can take attributes from the questionnaire where people lack trust and develop a mathematical model from security on the basis of those attributes.

\subsection{Statistical Tools:}

For our research study, we'll use Statistical Package for Social Sciences Version 16.0 (SPSS 16.0) for data storage and analysis and Ms Excel 2007 for analysing data collected from the questionnaire. The quantitative data would be analysed using graphs, tables, average mean etc, bi-variant data can be analysed using cross tabulation, using Chisquare, T-test, and Correlation etc. And for Report Writing have used Ms Word 2007.

\section{ANALYSIS AND INTERPRETATION}

\section{Hypothesis 1:}

H1O. There is no significant relationship between gender and maximum amount customers spend on online shopping.

\section{Data Analysis}

On running a Chi-Square test we get the following table

Table 1:Chi-Square Tests

\begin{tabular}{|l|l|l|l|}
\hline & & & $\begin{array}{l}\text { Asymp. } \\
\text { Sig. (2- } \\
\text { sided) }\end{array}$ \\
\hline Pearson Chi-Square & $69.226^{\mathrm{a}}$ & 6 & .000 \\
Likelihood Ratio & 76.558 & 6 & .000 \\
Linear-by-Linear & 43.613 & 1 & .000 \\
Association & 300 & & \\
N of Valid Cases & & & \\
\hline
\end{tabular}

Table 1:Chi-Square Tests

\begin{tabular}{|l|l|l|l|}
\hline & & & $\begin{array}{l}\text { Asymp. } \\
\text { Sig. (2- } \\
\text { sided) }\end{array}$ \\
\hline Palue & df & .000 \\
Likelihood Ratio & $69.226^{\mathrm{a}}$ & 6 & .000 \\
Linear-by-Linear & 76.558 & 6 & .000 \\
Association & 43.613 & 1 &
\end{tabular}

a. 2 cells $(14.3 \%)$ have expected count less than 5 . The minimum expected count is 4.55 .

From the table we see that:

Pearson Chi-Square $=69.226$

Degree of freedom $=6$

Sig value $=0.00$

Using degree of freedom and significance level we can decide whether we are able to reject the Null Hypothesis $\left(\mathrm{H}_{0}\right)$ of "There is no significant relationship between gender and maximum amount customers spend on online shopping”.

Table 2 :Critical Values Table

\begin{tabular}{|l|l|l|l|l|l|}
\hline $\begin{array}{l}\text { Degree } \\
\text { of } \\
\begin{array}{l}\text { Freedo } \\
\text { m (df) }\end{array}\end{array}$ & $\begin{array}{l}\text { Confidenc } \\
\text { e Level }\end{array}$ & $\begin{array}{l}0.10 \\
90 \%\end{array}$ & $\begin{array}{l}0.05 \\
95 \%\end{array}$ & $\begin{array}{l}0.01 \\
99 \%\end{array}$ & $\begin{array}{l}0.005 \\
99.5 \%\end{array}$ \\
\hline 6 & $\begin{array}{l}\text { Value of } \\
\text { Statistics }\end{array}$ & $\begin{array}{l}10.64 \\
5\end{array}$ & $\begin{array}{l}12.59 \\
2\end{array}$ & $\begin{array}{l}16.81 \\
2\end{array}$ & $\begin{array}{l}22.45 \\
8\end{array}$ \\
\hline
\end{tabular}

In order to reject the Null Hypothesis $\mathrm{H}_{0}$, our Chi- Square score must be greater than the critical value at the 0.05 level of significance .

From the table we find the Chi-Square statistic $=69.226$ and $\mathrm{df}=6$. So $\mathrm{P}$ value from Chi- Square distribution table comes out to be less than 0.05 . Since the value of statistic at $5 \%$ level of significance is 12.592 which is less than our calculated value of 69.226,is in the rejection region , so we have to reject the null hypothesis.

Hypothesis 2:

H20: There is no significant relationship between age and maximum amount spend on online shopping.

\section{Data Analysis}

On running the Pearson's correlation test we get the following table

Table 3 :Correlations

\begin{tabular}{|ll|l|l|}
\hline & Age & Q68MaxAmount \\
\hline Age & Pearson & 1 & $.219^{* *}$ \\
& Correlation & & \\
& Sig. (2-tailed) & & .000 \\
$\mathrm{~N}$ & 300 & 300 \\
\hline
\end{tabular}




\begin{tabular}{|ll|l|l|}
\hline $\begin{array}{l}\text { Q68MaxAmou } \\
\text { nt }\end{array}$ & Pearson & $.219^{* *}$ & 1 \\
& Correlation & & \\
& Sig. (2-tailed) & .000 & \\
$\mathrm{~N}$ & 300 & 300 \\
\hline
\end{tabular}

**. Correlation is significant at the 0.01 level (2-tailed).

Here, Pearson's Correlation is conducted to show that there is weak but positive correlation between the age of the respondents and the maximum amount spend on online shopping. The two -tailed test for significance value indicates that there is a statistically significant correlation between these two variables. In this, our Sig.(2- tailed) value is 0.000 . Since this value is less than 0.01 (which is our assumed alpha value). Because of this we can conclude that there is a weak statistically significant correlation between the age of the respondents and the maximum amount spend on online shopping. People in the age group of 25-40 years spends more on online shopping as they have the sense of saving and purchasing while the younger shoppers in the age group of less than 25 years have no experience and maturity to buy products with planned spending.

Thus we can say that there is a significant relationship between the age of the respondents and the maximum amount people spend on online shopping.

Correlation analysis shows that $\mathrm{H} 2_{0}$ is not supported. Thus there is a significant relationship between age of the respondents and the maximum amount people spend on online shopping $(\mathrm{r}=0.219, \mathrm{p}<0.01)$

Hypothesis 3:

H30: There is no significant relationship between the occupation and the maximum amount spend on online shopping.

\section{Data Analysis}

On running a Chi-Square test we get the following table

Table 4 :Chi-Square Tests

\begin{tabular}{|l|l|l|l|}
\hline & Value & df & $\begin{array}{l}\text { Asymp. Sig. } \\
\text { (2-sided) }\end{array}$ \\
\hline Pearson Chi-Square & $116.607^{\mathrm{a}}$ & 18 & .000 \\
Likelihood Ratio & 92.507 & 18 & .000 \\
Linear-by-Linear & 26.035 & 1 & .000 \\
Association & 300 & & \\
N of Valid Cases & 18 & \\
\hline
\end{tabular}

a. 12 cells (42.9\%) have expected count less than 5 . The minimum expected count is 1.65 .

From the table we see that:

\section{Pearson Chi-Square $=116.607$}

Degree of freedom $=18$

Sig value $=0.00$

Using degree of freedom and significance level we can decide whether we are able to reject the Null Hypothesis $\left(\mathrm{H}_{0}\right)$ of "There is no significant relationship between occupation and maximum amount customers spend on online shopping”
Table 5: Critical Values Table

\begin{tabular}{|l|l|l|l|l|l|}
\hline $\begin{array}{l}\text { Degree } \\
\text { of } \\
\begin{array}{l}\text { Freedo } \\
\text { m (df) }\end{array}\end{array}$ & $\begin{array}{l}\text { Confidenc } \\
\text { e Level }\end{array}$ & $\begin{array}{l}0.10 \\
90 \%\end{array}$ & $\begin{array}{l}0.05 \\
95 \%\end{array}$ & $\begin{array}{l}0.01 \\
99 \%\end{array}$ & $\begin{array}{l}0.005 \\
99.5 \%\end{array}$ \\
\hline 18 & Critical & 25.98 & 28.86 & 34.80 & 44.43 \\
& Value & 9 & 9 & 5 & 5 \\
\hline
\end{tabular}

In order to reject the Null Hypothesis $\mathrm{H}_{0}$, our Chi- Square score must be greater than the critical value at the 0.05 level of significance.

From the table we find the Chi-Square statistic $=116.607$ and $\mathrm{df}=18$. So $\mathrm{P}$ value from Chi- Square distribution table comes out to be less than 0.05 . Since the value of statistic at $5 \%$ level of significance is 28.869 which is less than our calculated value of 116.607, is in the rejection region, so we have to reject the null hypothesis.

Hypothesis 4:

H40:There is no significant relationship between consumers online security and privacy concerns being the barriers andnot giving the credit card number to unprotected online shopping sites.

\section{Data Analysis}

On running the Spearman's rho correlation test we get the following table

\section{Correlations}

\begin{tabular}{|c|c|c|c|c|}
\hline & & & $\begin{array}{l}\text { Q58aBar } \\
\text { riersSec } \\
\text { Priv }\end{array}$ & $\begin{array}{l}\text { Q72CNo } \\
\text { Unprote } \\
\text { cted }\end{array}$ \\
\hline \multirow[t]{6}{*}{$\begin{array}{l}\text { Spearman } \\
\text { 's rho }\end{array}$} & \multirow[t]{3}{*}{$\begin{array}{l}\text { Q58aBarrier } \\
\text { sSecPriv }\end{array}$} & $\begin{array}{l}\text { Correlation } \\
\text { Coefficient }\end{array}$ & 1.000 & \\
\hline & & Sig. (2-tailed) & & .001 \\
\hline & & $\mathrm{N}$ & 300 & 300 \\
\hline & \multirow[t]{3}{*}{$\begin{array}{l}\text { Q72CNoUn } \\
\text { protected }\end{array}$} & $\begin{array}{l}\text { Correlation } \\
\text { Coefficient }\end{array}$ & $.194^{* *}$ & 1.000 \\
\hline & & Sig. (2-tailed) & .001 & \\
\hline & & $\mathrm{N}$ & 300 & 300 \\
\hline
\end{tabular}

For calculating the coefficient of correlation, the Bivariate Spearman's two - tailed correlation was used. Here we have used a statistical test called Spearman's Rank Correlation Coefficient which is done to check whether the correlation is really significant or it could have been the result of chance alone. Spearman rank-order correlation shows that there is avery weakbut positive correlation (relationship / association) between consumer's online security and privacy concern being the barriers for online shopping and not giving the credit card number on the internet to un protected sites.

- .00-.19 "very weak"

- . 20-.39 “weak"

- .40-.59 "moderate” 
- .60-.79 “strong”

- . $.80-1.0$ “very strong”

As our correlation coefficient value is 0.194 which means that it is a very weak but positive correlation. Correlation coefficient value of +1 indicates a positive correlation ie. If one variable increases other variable also increase which means as the consumers online privacy and security concerns being the barrier increases then not giving credit card number to unprotected sites also increases. The two tailed test for significance value indicates that there is a statistically significant correlation between these two variables. In this, our Sig.(2- tailed) value is 0.001 . Since this value is less than 0.01(which is our assumed alpha value). Because of this we can conclude that there is a very weak statistically significant correlation between online security and privacy concern being the barrier and not giving the credit card number to unprotected sites. Therefore, it can be concluded that consumers are not willing to give the credit card number to the unprotected sites if they perceive security and privacy concern being the barrier to online shopping.

Since the very weak , but positive correlation is observed between the consumer's online privacy and security concern being the barriers and not giving the credit card number to unprotected sites $(\mathrm{r}=0.194)$. Hence the null hypothesis "There is no significant relationship between consumer's online security and privacy concerns being the barriers and giving the credit card number to unprotected sites" is rejected at $1 \%$ level.

Hypothesis 5:

H50: There is no significant relationship between the authenticity or reputation of the online shopping company and not giving the credit card number on its website.

\section{Data Analysis}

On running the Spearman's rho correlation test we get the following table

Table 6 : Correlations

\begin{tabular}{|c|c|c|c|c|}
\hline & & & $\begin{array}{l}\text { Q54Aut } \\
\text { henticit } \\
\text { y }\end{array}$ & $\begin{array}{l}\text { Q72CNo } \\
\text { Unprotec } \\
\text { ted }\end{array}$ \\
\hline \multirow[t]{2}{*}{$\begin{array}{l}\text { Spearman' } \\
\text { s rho }\end{array}$} & $\begin{array}{l}\text { Q54Authenti } \\
\text { city }\end{array}$ & $\begin{array}{l}\text { Correlation } \\
\text { Coefficient } \\
\text { Sig. (2-tailed) } \\
\text { N }\end{array}$ & $\begin{array}{l}1.000 \\
300\end{array}$ & $\begin{array}{l}.133^{*} \\
.021 \\
300\end{array}$ \\
\hline & $\begin{array}{l}\text { Q72CNoUnp } \\
\text { rotected }\end{array}$ & $\begin{array}{l}\text { Correlation } \\
\text { Coefficient } \\
\text { Sig. (2-tailed) } \\
\text { N }\end{array}$ & $\begin{array}{l}.133^{*} \\
.021 \\
300\end{array}$ & $\begin{array}{l}1.000 \\
300\end{array}$ \\
\hline
\end{tabular}

*. Correlation is significant at the 0.05

level (2-tailed).

Here, Spearman's Rank -Order Correlation is conducted to show that there is very weak but positive correlation between the Reputation / Authenticity of the company and not giving credit card number to unprotected sites. The two -tailed test for significance value indicates that there is a statistically significant correlation between these two variables. In this, our Sig.(2- tailed) value is 0.021. Since this value is less than 0.05 (which is our assumed alpha value). Because of this we can conclude that there is a very weak statistically significant correlation between Reputation / Authenticity of the company and not giving the credit card number to unprotected sites. Therefore, it can be concluded that if the company is authentic, then it provides the customer the sense of safety and security of their financial transactions which means that the customers are more willing to give the credit card number for doing financial transactions to the sites which are reputed.

Since the very weak, but positive correlation is observed between the reputation/authenticity of the company and not giving the credit card number to unprotected sites( $\mathrm{r}=0.133)$. Hence the null hypothesis "There is no significant relationship between the authenticity or reputation of the online shopping company and not giving the credit card number on its website.” is rejected at 5\% level.

Hypothesis 6:

H60: There is no significant relationship between considering privacy as being important or unimportant and using cash on delivery as a preferred method for online shopping.

\section{Data Analysis}

On running a Chi-square test we get the following table

Table 7 :Chi-Square Tests

\begin{tabular}{|l|l|l|l|l|l|}
\hline & Value & df & $\begin{array}{l}\text { Asymp. } \\
\text { Sig. (2- } \\
\text { sided) }\end{array}$ & $\begin{array}{l}\text { Exact } \\
\text { Sig. (2- } \\
\text { sided) }\end{array}$ & $\begin{array}{l}\text { Exact } \\
\text { Sig. (1- } \\
\text { sided) }\end{array}$ \\
\hline $\begin{array}{l}\text { Pearson Chi- } \\
\text { Square } \\
\text { Continuity } \\
\text { Correction } \\
\text { bikelihood } \\
\text { Ratio } \\
\text { Fisher's Exact }\end{array}$ \\
$\begin{array}{l}\text { Test } \\
\text { Linear-by- }\end{array}$ \\
$\begin{array}{l}\text { Linear } \\
\text { Association } \\
\text { N of Valid }\end{array}$
\end{tabular}

a. 0 cells (.0\%) have expected count less than 5. The minimum expected count is 6.44 .

b. Computed only for

a 2x2 table

Using degree of freedom and significance level we can decide whether we are able to reject the Null Hypothesis $\left(\mathrm{H}_{0}\right)$ of "There is no significant difference privacy and using cash on delivery as a preferred method for payment on the internet” 
Table 8 : Critical Values Table

\begin{tabular}{|l|l|l|l|l|l|}
\hline $\begin{array}{l}\text { Degree } \\
\text { of } \\
\begin{array}{l}\text { Freedom } \\
\text { (df) }\end{array}\end{array}$ & $\begin{array}{l}\text { Confidence } \\
\text { Level }\end{array}$ & $\begin{array}{l}0.10 \\
90 \%\end{array}$ & $\begin{array}{l}0.05 \\
95 \%\end{array}$ & $\begin{array}{l}0.01 \\
99 \%\end{array}$ & $\begin{array}{l}0.005 \\
99.5 \%\end{array}$ \\
\hline 1 & $\begin{array}{l}\text { Critical } \\
\text { Value }\end{array}$ & 2.706 & 3.841 & 6.635 & 10.828 \\
\hline
\end{tabular}

In order to reject the Null Hypothesis $\mathrm{H}_{0}$, our Chi- Square score must be greater than the critical value at the 0.05 level of significance

From the table we find the Chi-Square statistic $=7.221$ and $\mathrm{df}=1$. So $P$ value from Chi- Square distribution table comes out to be less than 0.05 . Since the value of statistic at $5 \%$ level of significance is 3.841 which is less than our calculated value of 7.221, is in the rejection region, so we have to reject the null hypothesis.

Hypothesis 7:

H70: There is no significant relationship between risk of phishing credit card transactions and using credit card as a preferred method for payment on the internet.

\section{Data Analysis}

On running a Chi-Square test we get the following table

Table 9 :Chi-Square Tests

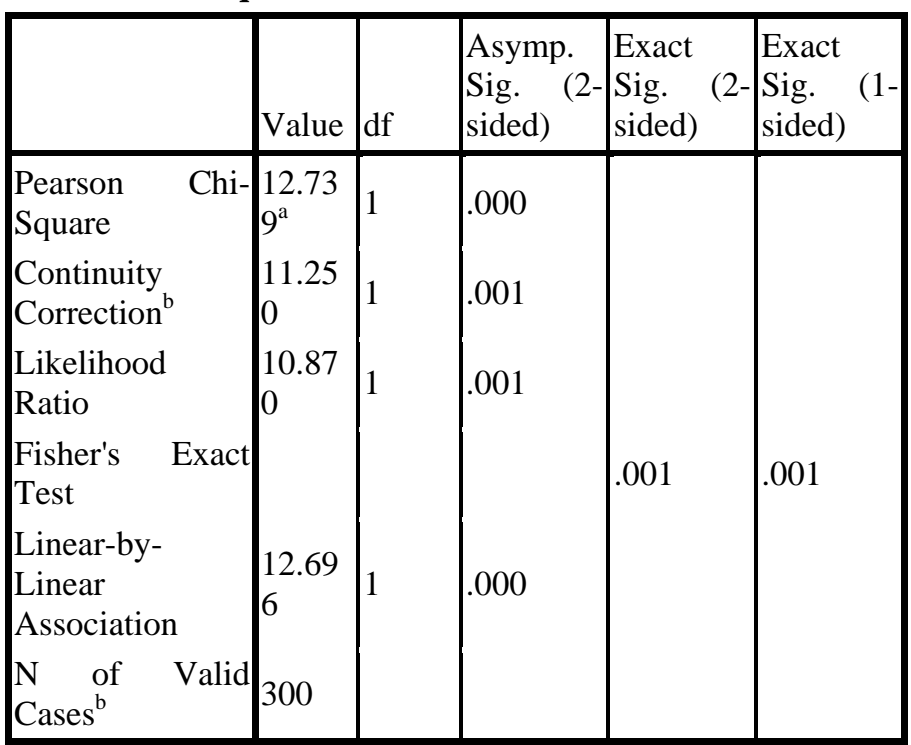

a. 0 cells $(.0 \%)$ have expected count less than 5 . The minimum expected count is 7.70 .

b. Computed only for a

2x2 table

From the table we see that:

Pearson Chi-Square $=12.739$

Degree of freedom $=1$

Sig value $=0.00$

Using degree of freedom and significance level we can decide whether we are able to reject the Null Hypothesis $\left(\mathrm{H}_{0}\right)$ of "There is no significant difference between risk of phishing credit card transactions and using credit card as a preferred method for payment on the internet”
Table 10 :Critical Values Table

\begin{tabular}{|l|l|l|l|l|l|}
\hline $\begin{array}{l}\text { Degree } \\
\text { of } \\
\begin{array}{l}\text { Freedom } \\
\text { (df) }\end{array}\end{array}$ & $\begin{array}{l}\text { Confidence } \\
\text { Level }\end{array}$ & $\begin{array}{l}0.10 \\
90 \%\end{array}$ & $\begin{array}{l}0.05 \\
95 \%\end{array}$ & $\begin{array}{l}0.01 \\
99 \%\end{array}$ & $\begin{array}{l}0.005 \\
99.5 \%\end{array}$ \\
\hline 1 & $\begin{array}{l}\text { Critical } \\
\text { Value }\end{array}$ & 2.706 & 3.841 & 6.635 & 10.828 \\
\hline
\end{tabular}

In order to reject the Null Hypothesis $\mathrm{H}_{0}$, our Chi- Square score must be greater than the critical value at the 0.05 level of significance

From the table we find the Chi-Square statistic $=12.739$ and $\mathrm{df}=1$. So $\mathrm{P}$ value from Chi- Square distribution table comes out to be less than 0.05 . Since the value of statistic at $5 \%$ level of significance is 3.841 which is less than our calculated value of 12.739 , is in the rejection region, so we have to reject the null hypothesis $\mathrm{H}_{0}$.

Hypothesis 8:

H80: There is no significant relationship between risk of phishing credit card transaction and using OTP (One Time Password) for secure transactions.

\section{Data Analysis}

On running a Chi-Square test we get the following table

Table 11 :Chi-Square Tests

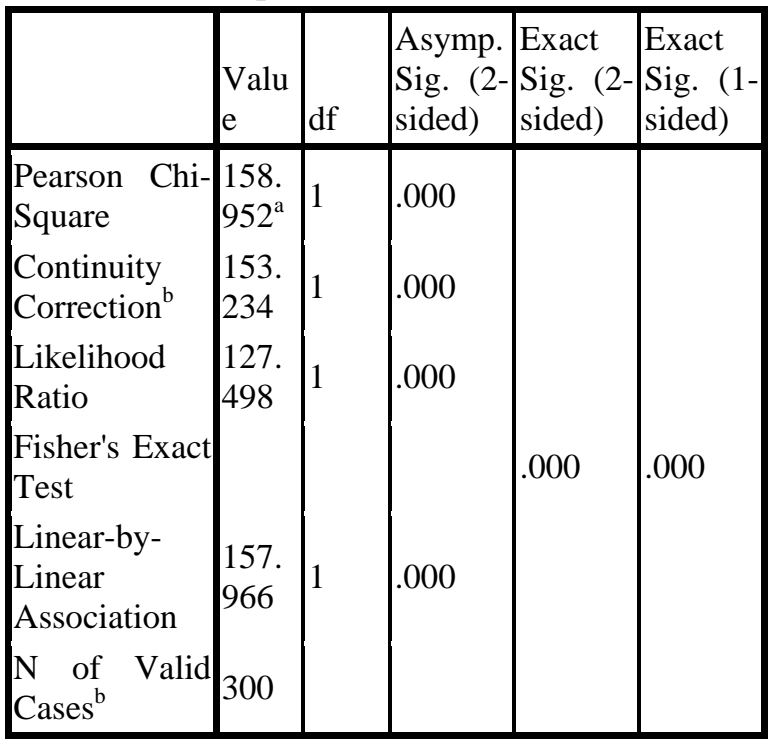

a. 0 cells $(.0 \%)$ have expected count less than 5 . The minimum expected count is 8.12.

b. Computed only

for a $2 \times 2$ table

From the table we see that:

Pearson Chi-Square $=158.952$

Degree of freedom $=1$

Sig value $=0.00$

Using degree of freedom and significance level we can decide whether we are able to reject the Null Hypothesis $\left(\mathrm{H}_{0}\right)$ of "There is no significant relationship between risk of 
phishing credit card transaction and using OTP (One Time Password) for secure transactions”.

Table 12 :Critical Values Table

\begin{tabular}{|l|l|l|l|l|l|}
\hline $\begin{array}{l}\text { Degree } \\
\text { of } \\
\text { Freedom } \\
\text { (df) }\end{array}$ & $\begin{array}{l}\text { Confidence } \\
\text { Level }\end{array}$ & $\begin{array}{l}0.10 \\
90 \%\end{array}$ & $\begin{array}{l}0.05 \\
95 \%\end{array}$ & $\begin{array}{l}0.01 \\
99 \%\end{array}$ & $\begin{array}{l}0.005 \\
99.5 \%\end{array}$ \\
\hline 1 & $\begin{array}{l}\text { Critical } \\
\text { Value }\end{array}$ & 2.706 & 3.841 & 6.635 & 10.828 \\
\hline
\end{tabular}

In order to reject the Null Hypothesis $\mathrm{H}_{0}$, our Chi- Square score must be greater than the critical value at the 0.05 level of significance .

From the table we find the Chi-Square statistic $=158.952$ and $\mathrm{df}=1$. So $\mathrm{P}$ value from Chi- Square distribution table comes out to be less than 0.05 . Since the value of statistic at $5 \%$ level of significance is 3.841 which is less than our calculated value of 158.952, is in the rejection region, so we have to reject the null hypothesis $\mathrm{H}_{0}$.

Hypothesis 9:

H90: There is no significant relationship between risk of phishing credit card transaction and using antivirus/antispyware software package.

\section{Data Analysis}

On running a Chi-Square test we get the following table Table 13 :Chi-Square Tests

\begin{tabular}{|l|l|l|l|}
\hline & Value & df & $\begin{array}{l}\text { Asymp. } \\
\text { Sig. (2- } \\
\text { sided) }\end{array}$ \\
\hline $\begin{array}{l}\text { Pearson Chi-Square } \\
\text { Likelihood Ratio } \\
\text { Linear-by-Linear } \\
\text { Association }\end{array}$ & 144.979 & 2 & .000 \\
N of Valid Cases & 300 & .000 \\
\hline
\end{tabular}

a. 1 cells (16.7\%) have expected count less than 5 .

The minimum expected count is 2.38 .

From the table we see that:

Pearson Chi-Square $=183.59$

Degree of freedom $=2$

Sig value $=0.00$

Using degree of freedom and significance level we can decide whether we are able to reject the Null Hypothesis $\left(\mathrm{H}_{0}\right)$ of "There is no significant relationship between risk of phishing credit card transaction and using antivirus/antispyware software package”.

Table 14 : Critical Values Table

\begin{tabular}{|l|l|l|l|l|l|}
\hline $\begin{array}{l}\text { Degree } \\
\text { of } \\
\begin{array}{l}\text { Freedom } \\
\text { (df) }\end{array}\end{array}$ & $\begin{array}{l}\text { Confidence } \\
\text { Level }\end{array}$ & $\begin{array}{l}0.10 \\
90 \%\end{array}$ & $\begin{array}{l}0.05 \\
95 \%\end{array}$ & $\begin{array}{l}0.01 \\
99 \%\end{array}$ & $\begin{array}{l}0.005 \\
99.5 \%\end{array}$ \\
\hline 2 & $\begin{array}{l}\text { Critical } \\
\text { Value }\end{array}$ & 4.605 & 5.991 & 9.210 & 13.816 \\
\hline
\end{tabular}

In order to reject the Null Hypothesis $\mathrm{H}_{0}$, our Chi- Square score must be greater than the critical value at the 0.05 level of significance .

From the table we find the Chi-Square statistic $=183.59$ and $\mathrm{df}=2$. So $\mathrm{P}$ value from Chi- Square distribution table comes out to be less than 0.05 . Since the value of statistic at $5 \%$ level of significance is 5.991 which is less than our calculated value of 183.59 , is in the rejection region, so we have to reject the null hypothesis $\mathrm{H}_{0}$.

Hypothesis 10:

H10 0: There is no significant relationship between security and privacy being the barriers to online shopping and maximum amount people spend on online shopping.

\section{Data Analysis}

On running a Chi-Square test we get the following table

Table 15 :Chi-Square Tests

\begin{tabular}{|c|c|c|c|}
\hline & Value & df & $\begin{array}{l}\text { Asymp. Sig. } \\
\text { (2-sided) }\end{array}$ \\
\hline $\begin{array}{l}\text { Pearson } \\
\text { Square }\end{array}$ & $\begin{array}{l}32.85 \\
9^{\mathrm{a}}\end{array}$ & 6 & .000 \\
\hline $\begin{array}{l}\text { Likelihood } \\
\text { Ratio }\end{array}$ & $\begin{array}{l}35.44 \\
9\end{array}$ & 6 & .000 \\
\hline $\begin{array}{l}\text { Linear-by- } \\
\text { Linear } \\
\text { Association }\end{array}$ & 3.994 & 1 & .046 \\
\hline $\begin{array}{l}\mathrm{N} \text { of } \text { Valid } \\
\text { Cases }\end{array}$ & 300 & & \\
\hline & & & \\
\hline
\end{tabular}

a. 2 cells (14.3\%) have expected count less than 5 . The minimum expected count is 3.25 .

From the table we see that:

Pearson Chi-Square $=32.859$

Degree of freedom $=6$

Sig value $=0.00$

Using degree of freedom and significance level we can decide whether we are able to reject the Null Hypothesis $\left(\mathrm{H}_{0}\right)$ of "There is no significant relationship between security and privacy being the barriers to online shopping and maximum amount people spend on online shopping.”.

Table 16 :Critical Values Table

\begin{tabular}{|l|l|l|l|l|l|}
\hline $\begin{array}{l}\text { Degree } \\
\text { of } \\
\begin{array}{l}\text { Freedo } \\
\text { m (df) }\end{array}\end{array}$ & $\begin{array}{l}\text { Confidenc } \\
\text { e Level }\end{array}$ & $\begin{array}{l}0.10 \\
90 \%\end{array}$ & $\begin{array}{l}0.05 \\
95 \%\end{array}$ & $\begin{array}{l}0.01 \\
99 \%\end{array}$ & $\begin{array}{l}0.005 \\
99.5 \%\end{array}$ \\
\hline 6 & Critical & 10.64 & $\begin{array}{l}12.59 \\
2\end{array}$ & $\begin{array}{l}16.81 \\
2\end{array}$ & $\begin{array}{l}22.45 \\
8\end{array}$ \\
\hline
\end{tabular}


In order to reject the Null Hypothesis $\mathrm{H}_{0}$, our Chi- Square score must be greater than the critical value at the 0.05 level of significance .

From the table we find the Chi-Square statistic $=32.859$ and $\mathrm{df}=6$. So $\mathrm{P}$ value from Chi- Square distribution table comes out to be less than 0.05 . Since the value of statistic at $5 \%$ level of significance is 12.592 which is less than our calculated value of 32.859 , is in the rejection region, so we have to reject the null hypothesis $\mathrm{H}_{0}$.

Hypothesis 11:

H11 0: There is no significant relationship between privacy of personal information being considered important and knowledge of $s$ in https://

\section{Data Analysis}

On running a Chi-Square test we get the following table

Table 17 :Chi-Square Tests

\begin{tabular}{|l|l|l|l|}
\hline & & & $\begin{array}{l}\text { Asymp. } \\
\text { Sig. (2- } \\
\text { sided) }\end{array}$ \\
\hline $\begin{array}{l}\text { Pearson Chi- } \\
\text { Square } \\
\text { Likelihood Ratio } \\
\text { a df }\end{array}$ & 57.521 & 2 & .000 \\
$\begin{array}{l}\text { Linear-by-Linear } \\
\text { Association } \\
\text { N of Valid Cases }\end{array}$ & 300 & .000 \\
\hline
\end{tabular}

a. 2 cells (33.3\%) have expected count less

than 5 . The minimum expected count is 1.84 .

From the table we see that:

Pearson Chi-Square $=93.154$

Degree of freedom $=2$

Sig value $=0.00$

Using degree of freedom and significance level we can decide whether we are able to reject the Null Hypothesis $\left(\mathrm{H}_{0}\right)$ of "There is no significant relationship between privacy of personal information being considered important or unimportant and knowledge of s in https://”.

Table 18 : Critical Values Table

\begin{tabular}{|l|l|l|l|l|l|}
\hline $\begin{array}{l}\text { Degree } \\
\text { of } \\
\text { Freedom } \\
\text { (df) }\end{array}$ & $\begin{array}{l}\text { Confidence } \\
\text { Level }\end{array}$ & $\begin{array}{l}0.10 \\
90 \%\end{array}$ & $\begin{array}{l}0.05 \\
95 \%\end{array}$ & $\begin{array}{l}0.01 \\
99 \%\end{array}$ & $\begin{array}{l}0.005 \\
99.5 \%\end{array}$ \\
\hline 2 & $\begin{array}{l}\text { Critical } \\
\text { Value }\end{array}$ & 4.605 & 5.991 & 9.210 & 13.816 \\
\hline
\end{tabular}

In order to reject the Null Hypothesis $\mathrm{H}_{0}$, our Chi- Square score must be greater than the critical value at the 0.05 level of significance .

From the table we find the Chi-Square statistic=93.154 and $\mathrm{df}=2$. So $\mathrm{P}$ value from Chi- Square distribution table comes out to be less than 0.05 . Since the value of statistic at $5 \%$ level of significance is 5.991 which is less than our calculated value of 93.154, is in the rejection region, so we have to reject the null hypothesis $\mathrm{H}_{0}$.

\section{LIMITATION OF THE STUDY}

- Sample size is limited to 300 customers which is not adequate to represent the whole population.

- In our research we study the views of online shopping from the customer's point and not from the point of dealers, wholesalers or retailers which performs the driving force to carry out the business operations.

- Using Convenience based sampling and not random sampling due to time constraint so because of this the responses provided might not be the true reflection of the population and the findings may not represent the customers as a whole, therefore any generalization of findings may not be $100 \%$ reliable..

- Lack of opinion from the research variables from consumers who do not shop online. as the variables in this study are involved with experiences, the target group is the customer with online shopping experience. This study does not examine the reactions of research variable from consumers with no online shopping experience because of online shopping experience are pre-selected. It is possible that consumers with no online shopping experience have different perceptions of perceived risks and risk reduction strategies could have been different.

- Here due to time and cost constraint, we have examined the factors affecting online shopping behaviour of the customers living in Delhi, NCR. It is quite evident that in other countries people have different perceptions regarding online shopping. So this study cannot be applied to the customers belonging to other countries.

\section{CONCLUSION}

The main purpose of this research study was to examine the online shopping behavior of the customers living in Delhi and NCR. The result of this study supported all 11 hypotheses.

This study found that Gender, Age and Occupation of the customers have the significant impact on the maximum amount spend on online shopping. The study revealed that more number of males in the age group of 25-40 years and who are working professionals spends more on online shopping than other categories.

The study found that customer's online security and privacy concerns are positively correlated with not giving the credit card number to unprotected online shopping sites. It means that customers are not willing to give credit card number to the unprotected sites if they perceive privacy and security concerns being the barriers to online shopping.

The study also found that there is a positive correlation between the reputation / authenticity of the company and not giving the credit card number to unprotected sites. It means that if the company is authentic, then it provides the customer the sense of safety and security of their financial transactions which means that the customers are more willing to give the credit card number for doing financial transactions to the sites which are reputed. 
From the study we also came to know that there is a significant impact of privacy being considered as important or unimportant on using cash on delivery as a preferred method of payment for online shopping. It means that if people consider privacy being important they are more likely to use cash on delivery for online shopping and if people consider privacy being unimportant they are less likely to use cash on delivery for online shopping.

The study also found that there is a significant relationship between risk of phishing credit card transactions and using credit card as a preferred method for payment on the internet. It means that if people consider risk of phishing being important they are less likely to use credit card for online shopping and if people consider risk of phishing being unimportant they are more likely to use credit card for online shopping.

The study also found that there is a significant impact of risk of phishing credit card transactions on using OTP(One Time Password) for secure transactions as well as on using antivirus/antispyware software package.

The study also found that there is a significant relationship between security and privacy being the barriers to online shopping and maximum amount people spend on online shopping.

And finally the study also found that there is a significant impact of privacy of personal information being considered as important on the knowledge of $\mathrm{s}$ in https://

\section{ACKNOWLEDGEMENT}

I would like to express sincere thanks to my supervisor Dr. Sunil Kumar Muttoo and also Dr. Sameer Anand for their valuable guidance in this paper.

\section{REFERENCES}

[1]. M.Mohanraj(2016).Customers perception about online shopping. $\quad$ Retrieved from https://books.google.co.in/books?isbn=1536901636

[2]. Privacy in E-commerce: A General Perspective [Word Document], Retrieved from web2.uwindsor.ca/courses/cs/aggarwal/.../XiaomingSejdiniC howdhury_Privacy.doc

[3]. Chung, W., \& Paynter, J. (2002, January). Privacy issues on the Internet. InSystem Sciences, 2002.HICSS. Proceedings of the 35th Annual Hawaii International Conference on(pp. 9-pp). IEEE.

[4]. Bandyopadhyay, Soumava. "Online privacy concerns of Indian consumers." The International Business \& Economics Research Journal 10.2 (2011): 93.

[5]. Dinev, Tamara, et al. "Privacy calculus model in ecommerce-a study of Italy and the United States." European Journal of Information Systems 15.4 (2006): 389-402..

[6]. Shah, Mahmood H., Ramanus Okeke, and Rizwan Ahmed. "Issues of privacy and trust in e-commerce: Exploring customers' perspective." Journal of Basic and Applied Scientific Research 3.3 (2013): 571-577.

[7]. Bandyopadhyay, Soumava. "Predicting Consumer Reaction To Online Privacy Concerns: A Nested Logit Model." International Journal of Management \& Information Systems (Online) 17.2 (2013): 89.

[8]. Mathur, Neeraj. "Perceived Risks towards Online Shopping." Group 2.1.00 (2015): 262.

[9]. Internet Payment System Retrieved From. http://www.referenceforbusiness.com/small/IncMail/Internet-Payment-Systems.html

[10]. Chaudhari, P., \& Das, M. L. (2017). Privacy Preserving Signcryption Scheme. In Distributed Computing and Internet Technology (pp. 196-209). Springer International Publishing.

\section{ONLINE SHOPPING QUESTIONNAIRE}

\section{Appendix 1}

\section{About the Study}

This Questionnaire is part of my Research Topic “The Study of Data Privacy in E-commerce”.

With the help of this questionnaire I, intend to gather information about online shopping behavior in one’s daily life. General online shopping trends, usage pattern, your concerns and significance of data privacy in e-commerce. Our main aim behind doing this Research was to infer the perception of consumers about online shopping. I designed the Questionnaire to know about the experiences of the consumers and to get a better insight into their mindset about internet shopping.

In this regards your kind cooperation is needed in filling the Questionnaire. Further I assure you that all the information provided by you would be kept strictly confidential and data from this research will be reported only in aggregate.

Directions As a part of our exploratory research, we request you to spare a few minutes in answering the questions below. Please read each question carefully and indicate your response by selecting the most appropriate choice.

\section{About You :}

\section{Name :}

$$
\text { DEMOGRAPHIC INFORMATION...... }
$$
1. Gender: Male
Female

2. Age

\begin{tabular}{|l|c|}
\hline Less than 25 & $\square$ \\
\hline $25-40$ & $B$ \\
\hline $40-45$ & $B$ \\
\hline Above 45 & $B$ \\
\hline
\end{tabular}

3. Occupation

\begin{tabular}{|l|l|}
\hline$\Gamma$ & Student \\
\hline
\end{tabular}




\begin{tabular}{|l|l|}
\hline$\Gamma$ & Professional \\
\hline$\Gamma$ & Government employed \\
\hline$\Gamma$ & Self employed \\
\hline$\Gamma$ & Others \\
\hline
\end{tabular}

4. Monthly Income

\begin{tabular}{|c|c|}
\hline Less than 5000 & $\Gamma$ \\
\hline $5000-10000$ & $\Gamma$ \\
\hline $10001-20000$ & $\bar{\Gamma}$ \\
\hline 20001-30000 & $\Gamma$ \\
\hline $30001-40000$ & $\bar{\Gamma}$ \\
\hline More than 40001 & $\bar{\Gamma}$ \\
\hline
\end{tabular}

In general, you prefer to do your online shopping of: (Select only one)

Very Often Sometimes Rarely Never Often

\begin{tabular}{|l|l|l|l|l|l|}
\hline Groceries & $\Gamma$ & $\Gamma$ & $\Gamma$ & $\Gamma$ & $\Gamma !$ \\
\hline $\begin{array}{l}\text { Fast } \\
\text { food }\end{array}$ & $\Gamma$ & $\Gamma$ & $\Gamma$ & $\Gamma$ & $\Gamma !$ \\
\hline Cosmetics & $\Gamma$ & $\Gamma$ & $\Gamma$ & $\Gamma$ & $\Gamma !$ \\
\hline
\end{tabular}

\begin{tabular}{|l|l|l|l|l|l|}
\hline Books & $\Gamma$ & $\Gamma$ & $\Gamma$ & $\Gamma$ & $\Gamma !$ \\
\hline CD/DVDs & $\Gamma$ & $\Gamma$ & $\Gamma$ & $\Gamma$ & $\Gamma !$ \\
\hline Toys & $\Gamma$ & $\Gamma$ & $\Gamma$ & $\Gamma$ & $\Gamma !$ \\
\hline Furniture & $\Gamma$ & $\Gamma$ & $\Gamma$ & $\Gamma$ & $\Gamma !$ \\
\hline Clothes & $\Gamma$ & $\Gamma$ & $\Gamma$ & $\Gamma$ & $\Gamma !$ \\
\hline Electronic Equipments (TV,Computer) & $\Gamma$ & $\Gamma$ & $\Gamma$ & $\Gamma$ & $\Gamma !$ \\
\hline Cinema/Concert/Theatre Ticket & $\Gamma$ & $\Gamma$ & $\Gamma$ & $\Gamma$ & $\Gamma !$ \\
\hline Airplane/Railways Tickets & $\Gamma$ & $\Gamma$ & $\Gamma$ & $\Gamma$ & $\Gamma !$ \\
\hline Tours/Hotel Reservation & $\Gamma$ & $\Gamma$ & $\Gamma$ & $\Gamma$ & $\Gamma !$ \\
\hline Services(Insurance,Mutual Funds etc.) & $\Gamma !$ & $\Gamma !$ & $\Gamma !$ & $\Gamma !$ & $\Gamma !$ \\
\hline Construction Material (Labour, Paint,Tiles etc) & $\Gamma !$ & $\Gamma !$ & $\Gamma !$ & $\Gamma !$ & $\Gamma !$ \\
\hline Property & $\Gamma !$ & $\Gamma !$ & $\Gamma !$ & $\Gamma !$ & $\Gamma !$ \\
\hline
\end{tabular}

Which of the following stores have you ever visited for online shopping?

\begin{tabular}{|l|l|l|}
\hline 20 & e-bay & - \\
\hline 21 & Jabong.com & - \\
\hline 22 & Flipkart & - \\
\hline 23 & Myantra & ․ \\
\hline
\end{tabular}




\begin{tabular}{|c|c|c|}
\hline 24 & Snap Deal & Г \\
\hline 25 & $\begin{array}{l}\text { MakeMyTrip } \\
\text { www.makemytrip.com/ }\end{array}$ & $\Gamma$ \\
\hline 26 & IRCTC www.irctc.co.in/ & $\Gamma$ \\
\hline 27 & www.mygrahak.com & $\Gamma$ \\
\hline 28 & futurebazaar.com/ & $\Gamma$ \\
\hline 29 & www.magicbricks.com/ & $\Gamma$ \\
\hline 30 & http://www.policybazaar.com/ & $\Gamma$ \\
\hline 31 & $\begin{array}{l}\text { McDonalds } \\
\text { http://mcdelivery.co.in/ }\end{array}$ & Г \\
\hline 32 & shopping.indiatimes.com & $\Gamma$ \\
\hline 33 & Other [Please Specify] & $\Gamma$ \\
\hline
\end{tabular}

34. What factors helps you to decide which site to use for online shopping? [Any One]

\begin{tabular}{|l|l|}
\hline Search Engine & \\
\hline $\begin{array}{l}\text { Personal } \\
\text { Recommendation }\end{array}$ & - \\
\hline Special offers on the site & ㄷ \\
\hline Online advertising & ㅍ \\
\hline TV advertising & ㅍ \\
\hline Others & - \\
\hline
\end{tabular}

35. By which method you prefer to make your payments on the internet? [ Any One]

\begin{tabular}{|l|l|}
\hline Credit card/ Debit Card & ㅍ \\
\hline Net Banking & - \\
\hline Cash On Delivery & ㄷ \\
\hline Any Other method & - \\
\hline
\end{tabular}

36. How would you describe your proficiency on the internet?

Novice - Just learning how to use internet 
-Intermediate - I feel comfortable when using internet

-Advanced - I can use most or all internet services

How important are the following factors in your decision to purchase goods from the internet?

\begin{tabular}{|l|l|l|l|l|}
\hline $\begin{array}{l}\text { Very } \\
\text { unimportant }\end{array}$ & unimportant & $\begin{array}{l}\text { Neither } \\
\text { Important nor } \\
\text { unimportant }\end{array}$ & Important & Very important \\
\hline 1 & 2 & 3 & 4 & 5 \\
\hline
\end{tabular}

\begin{tabular}{|c|c|c|c|c|c|c|}
\hline & & $\mathbf{1}$ & 2 & 3 & 4 & 5 \\
\hline 37 & Wide choices of products and brands & $\Gamma$ & $\Gamma$ & $\Gamma$ & $\Gamma$ & $\Gamma$ \\
\hline 38 & Ease of shopping at home & $\Gamma$ & $\Gamma$ & $\Gamma$ & $\Gamma$ & $\Gamma$ \\
\hline 39 & Reduces travel time and cost & $\Gamma$ & $\Gamma$ & $\Gamma$ & $\Gamma$ & $\Gamma$ \\
\hline 40 & Anytime, anywhere 24 X 7 shopping. & $\Gamma$ & $\Gamma$ & $\Gamma$ & $\Gamma$ & $\Gamma$ \\
\hline 41 & Product / Delivery time & $\Gamma$ & $\Gamma$ & $\Gamma$ & $\Gamma$ & $\Gamma$ \\
\hline 42 & $\begin{array}{l}\text { Reputation / Authenticity of the company (Fake/ } \\
\text { genuine) }\end{array}$ & $\Gamma$ & $\Gamma$ & $\Gamma$ & $\Gamma$ & Г \\
\hline 43 & Guarantees and Warrantees & $\Gamma$ & $\Gamma$ & Г & $\Gamma$ & $\Gamma$ \\
\hline 44 & Privacy of the personal information & $\Gamma$ & $\Gamma$ & Г & $\Gamma$ & Г \\
\hline 45 & Good description of goods via images and videos & $\Gamma$ & $\Gamma$ & $\Gamma$ & $\Gamma$ & $\Gamma$ \\
\hline 46 & Discounts and offers & $\Gamma$ & $\Gamma$ & $\Gamma$ & $\Gamma$ & $\Gamma$ \\
\hline 47 & $\begin{array}{l}\text { Security and privacy concerns are barriers for my } \\
\text { shopping online. }\end{array}$ & $\Gamma$ & $\Gamma$ & Г & $\Gamma$ & Г \\
\hline 48 & Risk of phishing credit card transactions & $\Gamma$ & $\Gamma$ & $\Gamma$ & $\Gamma$ & $\Gamma$ \\
\hline 49 & Difficulty in returning products / items & $\Gamma$ & $\Gamma$ & $\Gamma$ & $\Gamma$ & $\Gamma$ \\
\hline 50 & Risk of not getting what I paid for & $\Gamma$ & $\Gamma$ & $\Gamma$ & $\Gamma$ & $\Gamma$ \\
\hline 51 & Not skillful with the internet & $\Gamma$ & $\Gamma$ & $\Gamma$ & $\Gamma$ & $\Gamma$ \\
\hline 52 & Earning Reward points on the credit card & $\Gamma$ & $\Gamma$ & $\Gamma$ & $\Gamma$ & $\Gamma$ \\
\hline 53 & Lack of trustworthiness of Vendors & $\Gamma$ & $\Gamma$ & $\Gamma$ & $\Gamma$ & $\Gamma$ \\
\hline 54 & $\begin{array}{l}\text { Complex compared to traditional shopping } \\
\text { (password) }\end{array}$ & $\Gamma$ & $\Gamma$ & $\Gamma$ & $\Gamma$ & Г \\
\hline 55 & $\begin{array}{l}\text { Not being able to touch and feel the products } \\
\text { (intangible) }\end{array}$ & $\Gamma$ & $\Gamma$ & $\Gamma$ & $\Gamma$ & $\Gamma$ \\
\hline 56 & More expensive than those sold in retail stores & $\Gamma$ & $\Gamma$ & $\Gamma$ & $\Gamma$ & $\Gamma$ \\
\hline 57 & I have undergone bad experience & $\Gamma$ & $\Gamma$ & $\Gamma$ & $\Gamma$ & $\bar{\Gamma}$ \\
\hline
\end{tabular}

58. Select an approximate maximum amount, you would spend on a single online purchase :

\begin{tabular}{|l|l|}
\hline$\Gamma \quad$ Less than 500 \\
\hline$\Gamma \quad$ Rs $501-1000$ \\
\hline$\Gamma \quad$ Rs $1001-2000$ \\
\hline$\Gamma \quad$ Rs $2001-5000$ \\
\hline$\Gamma \quad$ Rs $5001-10000$ \\
\hline
\end{tabular}




\begin{tabular}{|l|}
\hline$\square_{\text {Rs }} 10001$ - 15000 \\
\hline$\square_{\text {Above } 15000}$
\end{tabular}

\section{Information Security Awareness}

59. Do you read the Privacy Policy/ check the certificates of the website before entering credit card details or personal information?

\begin{tabular}{|l|}
\hline$\Gamma$ Always \\
\hline$\Gamma$ Sometimes \\
\hline$\Gamma$ Never \\
\hline
\end{tabular}

60. Regarding Antivirus / Antispyware protection, are the systems that you use (for online shopping) protected by an antivirus / anti-spyware software package(s)?

\begin{tabular}{|l|}
\hline$\Gamma_{\text {Yes }}$ \\
\hline$\Gamma_{\text {No }}$ \\
\hline$\Gamma_{\text {I do not know }}$ \\
\hline
\end{tabular}

61. Do you know what the $s$ in https:// means

\begin{tabular}{|l|}
\hline$\Gamma_{\text {Yes }}$ \\
\hline$\Gamma_{\text {No }}$ \\
\hline$\Gamma_{\text {I do not know }}$ \\
\hline
\end{tabular}

62. Do you give your credit card number on the Internet to unprotected sites ?

\begin{tabular}{|l|}
\hline$\Gamma_{\text {Yes }}$ \\
\hline$\Gamma_{\text {No }}$ \\
\hline$\Gamma_{\text {I do not know }}$ \\
\hline
\end{tabular}

63. What is very important for you?

\begin{tabular}{|l|}
\hline$\Gamma$ Convenience \\
\hline$\Gamma$ Privacy \\
\hline$\Gamma$ Both \\
\hline
\end{tabular}

64. Do you look for Privacy Seals like TRUSTe, VeriSign Trust Seal ,WebTrust before purchasing goods online?

\begin{tabular}{|l|}
\hline$\Gamma_{\text {Yes }}$ \\
\hline$\Gamma_{\text {No }}$ \\
\hline
\end{tabular}

65. Cookies are files that are sent from certain sites to your computer, which monitor your movement on the Internet and send data to certain sites, were you aware of this?

\begin{tabular}{|l|}
\hline$\Gamma_{\text {Yes }}$ \\
\hline$\Gamma_{\text {No }}$ \\
\hline$\Gamma_{\text {Don't know }}$ \\
\hline
\end{tabular}


66. Do you delete cookies after you purchase goods online?

\begin{tabular}{|l|}
\hline$\Gamma$ Always \\
\hline$\Gamma$ Sometimes \\
\hline$\Gamma$ Never \\
\hline
\end{tabular}

67. Do you always print or save copies of your order?

\begin{tabular}{|l|l|}
\hline$\Gamma$ Yes \\
\hline$\Gamma_{\text {No }}$ \\
\hline
\end{tabular}

69. Have you heard of these technologies?

\begin{tabular}{|l|l|l|l|}
\hline & Never & Heard & $\begin{array}{l}\text { I know how they } \\
\text { work }\end{array}$ \\
\hline Firewall & $\Gamma$ & $\Gamma$ & $\Gamma$ \\
\hline SSL & $\Gamma$ & $\Gamma$ & $\Gamma$ \\
\hline SET & $\Gamma$ & $\Gamma$ & $\Gamma$ \\
\hline $\begin{array}{l}\text { Encryption / } \\
\text { Decryption }\end{array}$ & $\Gamma$ & $\Gamma$ & $\Gamma$ \\
\hline Site certification & $\Gamma$ & $\Gamma$ & $\Gamma$ \\
\hline
\end{tabular}

70. Which technology do you prefer for secure transactions?

$\lceil$ Security Device (Like USB, sentinel device which generates a random password)

One Time Password(Password valid for a particular session) Along with the Transaction Password

Г Security Questions along with the Transaction Password

3D Secure Password

Additional Security (apart from the security provided by Application Software

71. Do you feel there is a need of enhancement in security?

\begin{tabular}{|l|}
\hline$\Gamma_{\text {Yes }}$ \\
\hline$\Gamma_{\text {Neutral }}$ \\
\hline$\Gamma_{\text {No }}$ \\
\hline
\end{tabular}

72. What actions do you think can improve the online security of confidential information?

\begin{tabular}{|l|}
\hline New laws related to online behaviour \\
\hline $\begin{array}{l}\text { Two factor authentication(eg. Non duplicate digital certificate,token based one time } \\
\text { password }\end{array}$ \\
\hline \begin{tabular}{l}
$\Gamma$ Biometric security measure (eg. Finger print identification , signature recognition) \\
\hline \\
Using security programs ( Anti - virus software, personal firewalls, Anti - Spyware)
\end{tabular} \\
\hline$\quad$ All of the above. \\
\hline
\end{tabular}

Thanks you very much for your time and support 